\title{
Large-scale climate variability and rodent abundance modulates recruitment rates in Willow Ptarmigan (Lagopus lagopus)
}

\author{
Mikkel A. J. Kvasnes • Hans Chr. Pedersen • \\ Torstein Storaas $\cdot$ Erlend B. Nilsen
}

Received: 30 September 2013/Revised: 29 March 2014/Accepted: 14 April 2014/Published online: 6 May 2014

(C) The Author(s) 2014. This article is published with open access at Springerlink.com

\begin{abstract}
Recruitment of juveniles is important for the size of the next year's breeding population in many bird species. Climate variability and predation may affect recruitment rates, and when these factors are spatially correlated, recruitment rates in spatially separated populations of a species may be synchronized. We used production data from an extensive survey of Willow Ptarmigan from 2000 to 2011 to investigate spatial synchrony in recruitment of juveniles within and among mountain region populations. In addition, we assessed the effects of predation and large—as well as local—scale climate on recruitment of juveniles. Recruitment was synchronized both within and among mountain regions, but the mean spatial correlation was strongest among mountain regions. This may be caused by small-scale factors such as predation or habitat structure, or be a result of sampling variation, which may be large at small spatial scales. The strong synchrony suggests that populations are subject to similar environmental forces. We used mixed effect models at the survey area and mountain region scales to assess the effect of rodent abundance (a proxy for predation rates) and local and regional climate during the breeding season on the recruitment of juvenile birds. Model selection based on AICc revealed that the most parsimonious models at both spatial scales included positive effects of rodent abundance
\end{abstract}

Communicated by F. Bairlein.

M. A. J. Kvasnes $(\bowtie) \cdot$ T. Storaas

Faculty of Applied Ecology and Agricultural Sciences, Hedmark

University College, Evenstad, 2418 Elverum, Norway

e-mail: mikkelkvasnes@hotmail.com

H. Chr. Pedersen - E. B. Nilsen

Norwegian Institute for Nature Research, Box 5685 Sluppen,

7485 Trondheim, Norway and the North Atlantic oscillation during May, June and July $\left(\mathrm{NAO}_{\mathrm{MJJ}}\right)$. The $\mathrm{NAO}_{\mathrm{MJJ}}$ index was positively related to temperature and precipitation during the pre-incubation period; temperature during the incubation period and positive $\mathrm{NAO}_{\mathrm{MJJ}}$ values accelerate plant growth. A comparison of the relative effects of $\mathrm{NAO}_{\mathrm{MJJ}}$ and rodent abundance showed that variation in $\mathrm{NAO}_{\mathrm{MJJ}}$ had greatest impact on the recruitment of juveniles. This suggests that the climate effect was stronger than the effect of rodent abundance in our study populations. This is in contrast to previous studies on Willow Ptarmigan, but may be explained by the collapse in rodent cycles since the 1990s. If Willow Ptarmigan dynamics in the past were linked to the rodent cycle through a shared predator regime, this link may have been weakened when rodent cycles became more irregular, resulting in a more pronounced effect of environmental perturbation on the dynamics of ptarmigan.

Keywords Spatial synchrony $\cdot$ NAO $\cdot$ Recruitment of juveniles · Ptarmigan - Temperature - Precipitation . Breeding season - Alternative prey hypothesis - Local weather $\cdot$ Breeding success . Onset of plant growth

\section{Zusammenfassung}

Großräumige klimatische Schwankungen und Abundanz von Nagetieren bestimmen die Rekrutierungsraten von Moorschneehühnern Lagopus lagopus

Die Rekrutierung von Juvenilen ist von großer Bedeutung für die Größe der Brutpopulation vieler Vogelarten im folgenden Jahr. Klimaschwankungen und Prädation können Rekrutierungsraten beeinflussen. Wenn solche Faktoren räumlich korreliert sind, können Rekrutierungsraten in räumlich getrennten Populationen synchronisiert sein. Wir 
nutzten Brutdaten einer umfangreichen Bestandsaufnahme von Moorschneehühnern aus den Jahren 2000-2011 zur Untersuchung räumlicher Synchronie in der Rekrutierung von Juvenilen innerhalb und zwischen Populationen in Bergregionen. Darüber hinaus schätzten wir die Effekte von Prädation und groß- wie kleinräumigem Klima auf die Rekrutierung von Juvenilen ein. Die Rekrutierung war sowohl innerhalb als auch zwischen Bergregionen synchronisiert, wobei die durchschnittliche räumliche Korrelation am stärksten zwischen den Bergregionen war. Die könnte durch kleinskalige Faktoren wie Prädation oder Habitatstruktur begründet sein oder aber durch unterschiedliche Stichproben, die größer sein können bei kleinen Maßstäben. Die starke Synchronie deutet darauf hin, dass die Populationen ähnlichen Umwelteinflüssen ausgesetzt sind. Wir wendeten Gemischte Modelle auf Untersuchungsgebiet und Bergregion an, um den Einfluss der Nagerabundanz (Parameter für Prädationsraten) sowie lokales und regionales Klima während der Brutsaison auf die Rekrutierung juveniler Vögel zu berechnen. Die Modellauswahl basierend auf AICs zeigte, dass die minimalsten Modelle auf beiden räumlichen Skalen positive Effekte auf die Nagerdichte und die nordatlantische Oszillation im Mai, Juni und Juli $\left(\mathrm{NAO}_{\mathrm{MJJ}}\right)$ beinhalten. Der $\mathrm{NAO}_{\mathrm{MJJ}}$ Index war positiv verbunden mit der Temperatur und Niederschlag in der Vorbrutzeit. Temperatur während der Bebrütungsphase und positive $\mathrm{NAO}_{\mathrm{MJJ}}$ Werte überstiegen das Pflanzenwachstum. Ein Vergleich der relativen Effekte von $\mathrm{NAO}_{\mathrm{MJJ}}$ und Nagerdiche zeigten, dass Schwankungen des $\mathrm{NAO}_{\mathrm{MJJ}}$ den größten Einfluss auf die Rekrutierung von Juvenilen haben. Das deutet darauf hin, dass klimatische Effekte stärker wirkten auf die untersuchten Populationen als die Nagerabundanz. Dies steht im Gegensatz zu vorherigen Untersuchungen an Moorschneehühnern, könnte aber erklärt werden durch den Zusammenbruch der Nagerzyklen seit den 1990er Jahren. Wenn die Dynamik von Moorschneehuhn Populationen in der Vergangenheit gekoppelt war mit den Nagerzyklen durch ein gemeinsames Prädatorenregime, dann kann diese Beziehung geschwächt worden sein, als die Nagerzyklen unregelmäßiger wurden. Dies resultiert in einem stärker ausgeprägten Einfluss von störenden Umwelteinflüssen auf die Dynamik von Moorschneehühnern.

\section{Introduction}

For many bird species, changes in abundance are closely related to recruitment of juveniles in the preceding breeding season (Newton 1998), although density-dependent effects during the winter might weaken this link (Reed et al. 2013). Recruitment of juveniles in birds is strongly dependent on biotic factors such as predation on eggs and chicks (Newton 1998) and abiotic factors like weather conditions before and during the breeding season (Saether et al. 2004; Newton 1998). Spatial autocorrelation in predation (Ims and Andreassen 2000) or weather (Moran 1953; Grenfell et al. 1998; Kvasnes et al. 2010) across large areas can potentially force demographic rates of spatially structured populations into synchrony. Although adjacent populations may experience similar weather events, their dynamics can, nonetheless, be out of phase due to differences in local factors such as predator density or habitat (Tavecchia et al. 2008), or as an effect of sampling variation or demographic stochasticity, which may be larger on smaller scales due to reduced sample sizes (Tedesco et al. 2004; Lande et al. 2003).

Species with short generation times and high per-capita reproductive capacities are suitable targets for examining the effects of environmental conditions as their dynamics suggest sensitivity to variation in environmental conditions (Morris et al. 2008). The Willow Ptarmigan (Lagopus lagopus) is a medium-sized grouse distributed in alpine tundra habitats in the northern hemisphere (Johnsgard 1983). They have a short generation time $(T=1.8$, Sandercock et al. 2005 and annual mortality $>46 \%$, Sandercock et al. 2011; Smith and Willebrand 1999) and each female may produce up to 12 chicks annually, although recruitment of juveniles as well as densities of breeding birds vary both in time and space (Johnsgard 1983; Kvasnes et al. 2013). Several studies have documented that weather conditions during the breeding season can influence recruitment rates in ptarmigan (Hannon and Martin 2006; Novoa et al. 2008; Slagsvold 1975; Martin and Wiebe 2004; Steen et al. 1988a, b). A general finding is a positive effect of early onset of spring, i.e. warm weather and rainfall before laying and during incubation causing early snowmelt and early onset of the plant growth season (Rock Ptarmigan [Lagopus muta]; Novoa et al. 2008 and Willow Ptarmigan; Slagsvold 1975; Steen et al. 1988a, b). It has further been proposed that an early onset of plant growth (OPG) positively affects maternal nutrition during the prelaying period, which in turn enhances the viability of newly hatched chicks (Moss and Watson 1984; Steen et al. 1988a). Timing of plant growth may also affect viability of young chicks through its effect on availability of important insect prey species (Erikstad 1985b; Erikstad and Spidso 1982) that live on and off the vegetation (Erikstad and Spidso 1982). Young chicks need to be brooded by the hen, and the brooding frequency increases when the weather is cold and wet (Pedersen and Steen 1979; Erikstad and Spidso 1982). Thus, cold and wet weather during the brood rearing period may also reduce the viability of chicks since the time available for foraging is reduced (Erikstad and Spidso 1982; Erikstad and Andersen 1983). Studying 
causes of chick mortality in another tetraonid species, the Capercaillie (Tetrao urogallus), Wegge and Kastdalen (2007) observed high predation rates during and shortly after heavy rainfall, and the authors suggested that adverse weather predisposed chicks to predation. In general, ptarmigan are well adapted to variability within the normal range of their extreme environment (Martin and Wiebe 2004), but severe conditions, e.g. late snowmelt (Novoa et al. 2008; Martin and Wiebe 2004), delayed plant growth (Steen et al. 1988a), or heavy rainfall (Steen and Haugvold 2009) may negatively affect recruitment rates. Most studies investigating climate effects on ptarmigan populations have used local climate data (Martin and Wiebe 2004; Novoa et al. 2008; Steen et al. 1988b; Slagsvold 1975). However, Hornell-Willebrand et al. (2006) and Kvasnes et al. (2010) found large-scale synchrony in the recruitment of juvenile Willow Ptarmigan and rate of change in bag records, respectively, suggesting that driving factors may work across large areas. In fact, the rate of change in Willow Ptarmigan bag records were more synchronous within large regions of similar precipitation than between regions, suggesting that weather effects may affect population dynamics across large areas (Kvasnes et al. 2010). Similar large-scale effects have been found in Black Grouse (Tetrao tetrix) (Barnagaud et al. 2011).

Predation rates on eggs and chicks are generally high and can potentially have a great impact on annual recruitment in Willow Ptarmigan populations (Myrberget 1988; Steen and Haugvold 2009; Smith and Willebrand 1999). Recruitment rates of ptarmigan are often synchronized with the abundance of small rodents (Steen et al. 1988b; Myrberget 1988; Kausrud et al. 2008) and it has been suggested that the link between rodents and Willow Ptarmigan is a shared predator regime. The "alternative prey hypothesis" predicts that a shift occurs in the diet of generalist predators (i.e. Red Fox [Vulpes vulpes], Pine Marten [Martes martes] and Stoat [Mustela erminea]), from main prey (rodents [Microtus spp.]) to alternative prey (Ptarmigan and hares [Lepus spp.]), during rodent crashes and vice versa (Hagen 1952; Kjellander and Nordstrom 2003). Predation rates on eggs and chicks of Willow Ptarmigan may, therefore, increase as rodent populations decline. Steen et al. (1988b) and Myrberget (1988) found that rodent population cycles were regular with a 4-year periodicity and that this was coherent with the recruitment of juvenile Willow Ptarmigan. Fluctuations in rodent populations have, however, become more irregular during the last two decades (Kausrud et al. 2008; Ims et al. 2008) than before 1983 (Myrberget 1988; Steen et al. 1988a, b). This apparent collapse in regular periodicity of rodent dynamics has been ascribed to changes in climatic conditions during winter (Ims et al. 2008; Cornulier et al. 2013; Kausrud et al. 2008). It is likely that this also affects alternative prey species in mountain areas (Kausrud et al. 2008). In addition, the timing of a rodent crash can be important for recruitment of juvenile birds. If the rodent population crashes before fledging, the effects on alternative prey may be more severe than if the crash occurs after most chicks have fledged, as fledged chicks are capable of escaping mammalian predators (Erikstad 1985a).

We used Willow Ptarmigan survey data from 60 survey areas in south-central Norway from 2000 to 2011 (3-12 years per area) to investigate: (1) the degree of synchrony in the recruitment of juveniles within and among mountain region populations, and (2) the effect of predation and large-as well as local-scale climate on local and regional recruitment rates in Willow Ptarmigan. To our knowledge, no other studies have used such an extensive survey to investigate how extrinsic environmental factors shape the temporal variation in the recruitment of juvenile Willow Ptarmigan.

\section{Methods}

Data collection and study areas

Line-transect surveys were conducted in August from 1996 to 2011 in up to 60 survey areas across south-central and eastern Norway (Fig. 1). Four areas were surveyed from 1996, and new areas were subsequently added to the study design throughout the period. For practical reasons (weather, illness, shortage of voluntary field workers etc.), surveys were not conducted in all survey areas in all years and not all transects were sampled in a survey area every year. Because of the sub-alpine distribution of Willow Ptarmigan, survey areas were geographically clustered within five mountain regions (Fig. 1). Volunteer dog handlers with pointing dogs walked along predetermined transect lines and the free-running dogs searched the area on both sides of the line following the procedure of distance sampling (Buckland et al. 2001; Pedersen et al. 1999, 2004; Warren and Baines 2011). At each encounter, the number of birds (chicks, adult males, adult females and birds of unknown age/sex) and perpendicular distance from the transect line to the observed birds (m) were recorded. Pedersen et al. (2004) provide a detailed description of the sampling protocol. The number of years with data in each survey area varied between three and $15($ median $=7)$; the number of transects per survey area varied between two and 39 (median $=11)$, giving total transect lengths varying between 7.6 and $107 \mathrm{~km}$ (median $=33 \mathrm{~km}$ ); and the number of encounters per year per survey area varied between four and 179 (median = 30). The lowest total transect length, number of transects and number of encounters were independent of each other (not from the 


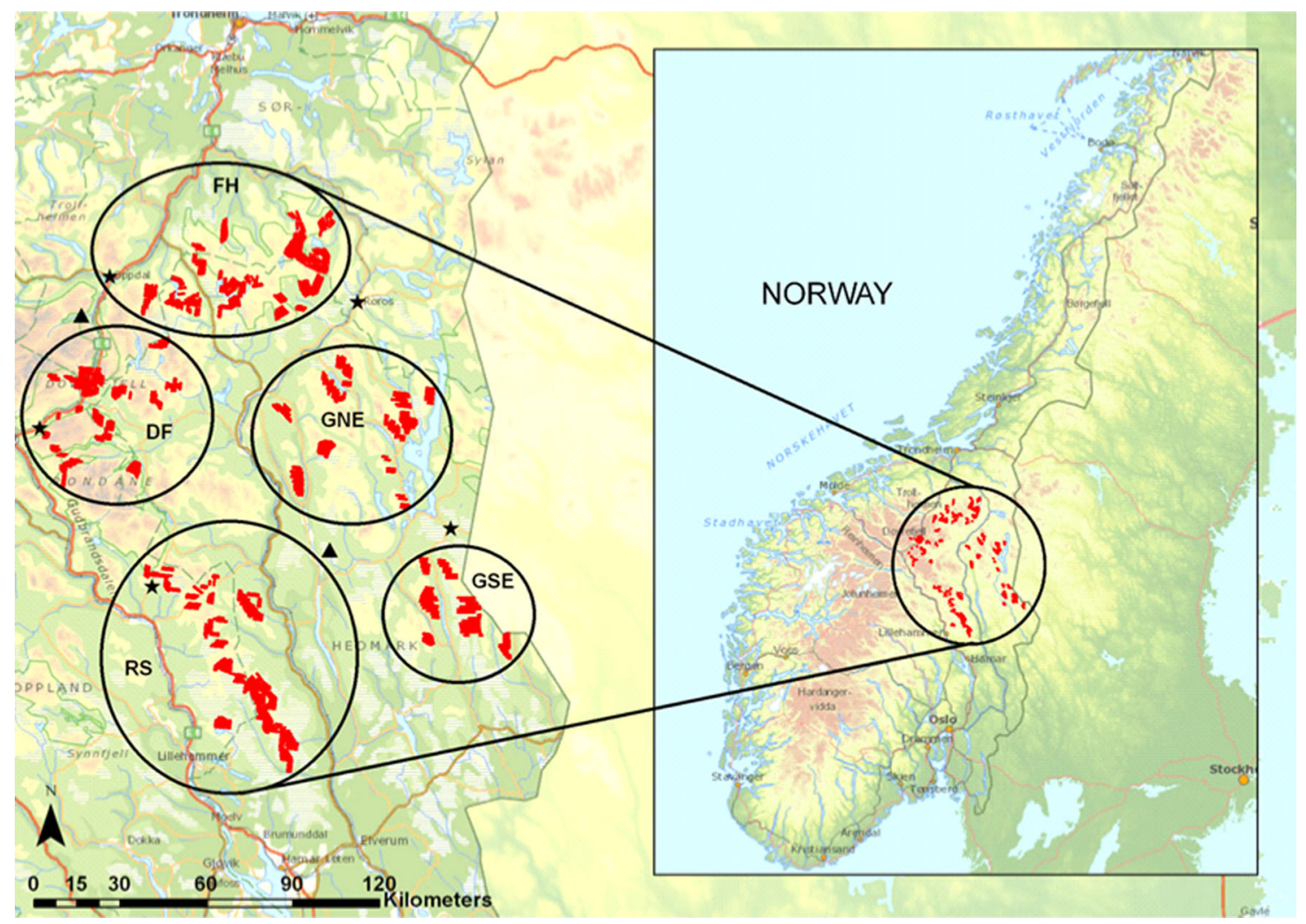

Fig. 1 Study areas (filled polygons) within mountain regions (open circles) in south-central Norway. RS Rondane, DF Dovre and Folldal, FH Forollhogna, GNE Glomma northeast, GSE Glomma southeast).

same area and year). Data from different transects were pooled per site and year.

We defined recruitment as the number of juveniles per pair in a given survey area a given year, based on the encounters described above. To obtain estimates of recruitment, we estimated the proportion of juveniles (PJ) from the raw data. We used data from all survey areas and years, but included only transect lines with recorded encounters, and only encounters where the sex and age class (i.e. no observations with unknown sex or age, c.f. above) were noted, including pairs without broods. The total number of observations was 16,468 (per mountain region: $\quad \mathrm{DF}=2,321, \quad \mathrm{FH}=6,672, \quad \mathrm{GNE}=1,735$, $\mathrm{GSE}=2,192$ and $\mathrm{RS}=3,548$, c.f. Fig. 1). To estimate the proportion of juveniles in each survey area each year, we used generalized mixed effect models with a logit link function for each mountain region separately (Crawley 2007), with number of juveniles/adult in each encounter as the dependent variable and a variable linking survey areas to year (called survey area-year) fitted as a random intercept. Then, we estimated the proportion of juveniles for each mountain region in each year by fitting a random intercept linking mountain region to year (called mountain region-year). This allowed us to estimate the proportion of
Filled stars and filled triangles are the positions of meteorological stations and rodent trap sites, respectively

juveniles from each encounter for each year in all survey areas and mountain regions separately. Large clusters are easier to detect than small clusters, and dogs spend more time searching close to the transect line than farther away (Pedersen et al. 2004). This might result in a size bias where average cluster size becomes larger at long distances compared to distances close to the transect line, and consequently, estimates of cluster size might be overestimated. As there is a positive correlation between cluster size and recruitment, we included distance from the transect line to the observation as a covariate in the models (Buckland et al. 2001). Consequently, we assumed that the effect of detection distance on cluster size was linear on the logit scale. While other relationships are also possible, low sample sizes in some areas/years would preclude more complex modelling of the relationship.

To estimate the recruitment of juveniles (number of juveniles/pair) we first estimated PJ, the proportion of juveniles in the sample estimated at the intercept (i.e. the back-transformed logit-value at the intercept). This corresponded to the proportion of juveniles at zero distance from the transect line, where detection probability is assumed to be one (Buckland et al. 2001). The number of juveniles/ pair was then estimated as: $\mathrm{PJ} /\left[\frac{1-\mathrm{PJ}}{2}\right]$. The total number of 
estimates was 464 and 60 for the survey area and mountain region scales, respectively.

Weather and rodent data

The breeding season was divided into three time periods: Pre-incubation (PRE-INC), Incubation (INC) and Brood (BROOD). Based on an average hatch date of 24 June (Erikstad et al. 1985), we backdated 21 days of incubation (Westerskov 1956) and defined this period (3-24 June) as the incubation period (INC). The period prior to incubation was defined as the pre-incubation period (PRE-INC), and included laying and pre-laying days (1 May-2 June), and we defined the period after hatching (25 June-15 July) as the brood rearing period (BROOD). At the end of this period, most chicks are fledged and mortality is reduced compared to the preceding periods (Erikstad 1985a).

\section{Local weather data}

We obtained data on mean daily temperature $\left({ }^{\circ} \mathrm{C}\right)$ and daily precipitation $(\mathrm{mm})$ from local meteorological stations located $>600 \mathrm{~m}$ above sea level. Not all stations recorded both temperature and precipitation, and many stations were opened or closed during our study period. Thus, we selected the five stations close to our survey areas with the most complete time series that included both temperature and precipitation data (Fig. 1). We measured distance between meteorological stations and the centre points of the survey areas and mountain regions. Ptarmigan data were then linked to data from the nearest meteorological station at both spatial scales. As a measure of temperature, we estimated the mean of all daily mean-temperatures $(T)$ in all periods $\left(T_{\text {PRE-INC }}, T_{\mathrm{INC}}\right.$, and $\left.T_{\mathrm{BROOD}}\right)$. Further we summed all daily precipitation in millimetres (RR) to obtain a measure of total precipitation in each period ( $\mathrm{RR}_{\mathrm{PRE}-\mathrm{INC}}, \mathrm{RR}_{\mathrm{INC}}$, and $\left.\mathrm{RR}_{\mathrm{BROOD}}\right)$. All local meteorological data were obtained from the open access database of the Norwegian Meteorological Institute at: http://www. eklima.met.no/.

\section{Onset of plant growth}

The OPG in spring is related to weather conditions such as snow-cover and temperature (Wielgolaski et al. 2011; Odland 2011). Variation in the timing of plant growth can possibly affect recruitment of juveniles through its effect on maternal nutrition and prey availability (Steen et al. 1988a; Moss and Watson 1984; Erikstad and Spidso 1982). To obtain estimates of OPG, we first used Geospatial Modelling Environment (Beyer 2012) to create minimum convex polygons (MCPs) for each mountain region, based on the centre points of survey areas within each region.
Then, we extracted OPG from MODIS satellite data from 2000 to 2011 separately for each mountain region. The time-series of MODIS data have been atmospheric corrected and the measurement of OPG is well correlated with field observations of the onset of leafing (Karlsen et al. 2009, 2012). Because of data deficiencies, the OPG estimates for Rondane and Glomma southeast were only based on parts of the mountain regions. Nonetheless, we believe the data were adequate since the general year to year variation was present, and the focus of this study is the temporal, rather than spatial variability in driving factors. The mean start of the growing season across all years and regions was 3 June, while the earliest mean start of the growing season was 28 May in 2011, and the latest mean start was 10 June in 2005.

\section{Large-scale climate variation}

Large-scale climatic variability, such as the North Atlantic oscillation (NAO), is known to impact on population dynamics and ecological processes in birds (Forchhammer and Post 2000; Stenseth et al. 2002; Barnagaud et al. 2011). The NAO gives an index of the difference in atmospheric pressure over the North Atlantic and, during winter, it strongly influences temperature and precipitation in Northern Europe (Hurrell 1995). The focus in this paper is climatic variability during the breeding season (cf. 1 May15 July, above), thus we choose to use a seasonal stationbased NAO-index for the period May, June and July $\left(\mathrm{NAO}_{\mathrm{MJJ}}\right)$ (Hurrell 2013) obtained from an open-access database at: https:/climatedataguide.ucar.edu/guidance/ hurrell-north-atlantic-oscillation-nao-index-station-based.

\section{Rodent abundance data}

Steen et al. (1988b) demonstrated that recruitment of juveniles was strongly related to variation in rodent abundance. Abundance of rodents can function as an index of predation rates if the alternative prey hypothesis (Kjellander and Nordstrom 2003; Hagen 1952) is valid. We obtained long term rodent trap data from two sites in our study area; Åmotsdalen from 1991 to 2011 (Framstad 2012; Selas et al. 2011) and Fuggdalen from 1974 to 2009 (Selas et al. 2011) (see Fig. 1). Rodents were caught in snap-traps in September and abundances were indexed as number of rodents caught per 100 trap nights. The dynamics of rodent populations is complex, but one important determinant is the winter climate (Cornulier et al. 2013; Ims et al. 2008; Kausrud et al. 2008), where favourable conditions during winter can result in high densities in early spring and vice versa. There is often a close relationship between spring and autumn densities of rodents (Kausrud et al. 2008); hence, data collected in 
September are likely to provide a good index of rodent abundance throughout the Willow Ptarmigan breeding season. We linked Willow Ptarmigan data from survey areas and mountain regions to the nearest rodent trapping site.

Since the OPG data were restricted to the period 2000-2011, we used this period as the time-frame for further analyses. Then we omitted 36 estimates from the survey areas including two survey areas that were lacking data after 2000. For the mountain region scale we omitted six estimates. Hence, when assessing spatial synchrony in the period 2000-2011, the data consisted of 428 (57 survey areas) and 54 (five mountain regions) estimates of juveniles/pair at the survey area and mountain region scale, respectively. Further, as there were missing records in the meteorological and rodent data series as well (c.f. above), the dataset used for investigating climatic and predation effects was additionally reduced to 330 (57 survey areas) and 40 (five mountain regions) estimates of juveniles/pair with corresponding predictor variables at the survey area and mountain region scale, respectively.

\section{Statistical analysis}

We assessed spatial synchrony in recruitment rates by constructing matrices of pair-wise Pearson cross-correlations, both between survey areas and between mountain regions. Because of a lack of statistical independence of pair-wise cross-correlations, we calculated mean crosscorrelation coefficients and confidence limits with a bootstrap procedure (Kvasnes et al. 2010). Pair-wise crosscorrelation coefficients were then sampled with replacement to generate 100,000 matrices of randomly drawn correlation coefficients (Crawley 2007). This distribution was then used to estimate the mean, together with 2.5 and $97.5 \%$ percentiles from the original matrix of pair-wise cross-correlation coefficients. We estimated bootstrapped means and percentiles across all survey areas, across survey areas within mountain regions and across mountain regions. We also assessed the level of synchrony in the rodent trap data by calculating a Pearson cross-correlation between the two trap sites.

The effect of climatic conditions and predation (indexed by rodent abundance) on recruitment of juveniles was modelled with linear mixed effect models at the survey area and mountain region scale (c.f. Fig. 1). We only considered additive effects and did not combine confounded variables. The local and regional climatic variables were modelled separately. At the survey area scale we included survey area, mountain region and year nested within mountain region as random effects, and at the mountain region scale we included mountain region and year as random effects. From the set of candidate models we used an information theoretic approach (Burnham and Anderson 2002) to select the most parsimonious model explaining the variation in recruitment of juveniles at survey area and mountain region scales, respectively. Because of the low sample size ( $\sim 12$ years), we used AICc as the selection criteria. $\triangle \mathrm{AICc}$ values of $<2$ suggest that the models are equally parsimonious, but in such cases we selected the simplest model. As the amount of variance explained $\left(R^{2}\right)$ by the explanatory variables can be of biological interest (Nakagawa and Schielzeth 2013), we estimated $R^{2}$ of the fixed effects from the most parsimonious models following the guides in Nakagawa and Schielzeth (2013).

To investigate how local conditions (weather variables and $\mathrm{OPG}$ ) were related to the NAO index, we fitted linear mixed effects models with local variables as dependent variables and $\mathrm{NAO}_{\mathrm{MJJ}}$ as fixed effect. Since local weather variables and OPG data were derived from different locations (five meteorological stations and five mountain regions, respectively), we considered two models for each variable: one with additive effects of location and $\mathrm{NAO}_{\mathrm{MJ}}$, and one with the interaction between the two terms. All models were fitted with year as random effect. We used an information theoretic approach (as described above) to select the most parsimonious model (Burnham and Anderson 2002), and we calculated bootstrapped confidence intervals and used these to evaluate if the slopes relating $\mathrm{NAO}_{\mathrm{MJJ}}$ to the climate variable of interest from the selected models were different from zero.

All statistical analyses were carried out using R (RCore-Team 2012). For the mixed effect models we used the lmer function in the lme4 package (Bates et al. 2011), and for the model selection procedure we used the MuMIn package (Barton 2013).

\section{Results}

Mean recruitment of juveniles across all survey areas varied from 3.52 juveniles/pair in 2009 to 5.84 juveniles/ pair in 2007, and the overall mean (2.5 and $97.5 \%$ percentiles) was estimated to be 4.76 juveniles/pair (4.62 and 4.90). At the mountain region scale, the mean ( 2.5 and $97.5 \%$ percentiles) recruitment of juveniles was 4.65 juveniles/pair (4.36 and 4.91) (Fig. 2).

Correlation in recruitment of juveniles between mountain regions in south-central Norway was generally high and significant (Table 1). The mean correlation between the five mountain regions was higher than between survey areas located within mountain regions (Table 2). Even though correlation coefficients between some pairs of mountain regions and some pairs of survey areas were not significant, the overall bootstrapped mean correlations were significantly positive (Table 1). The rodent trap data 

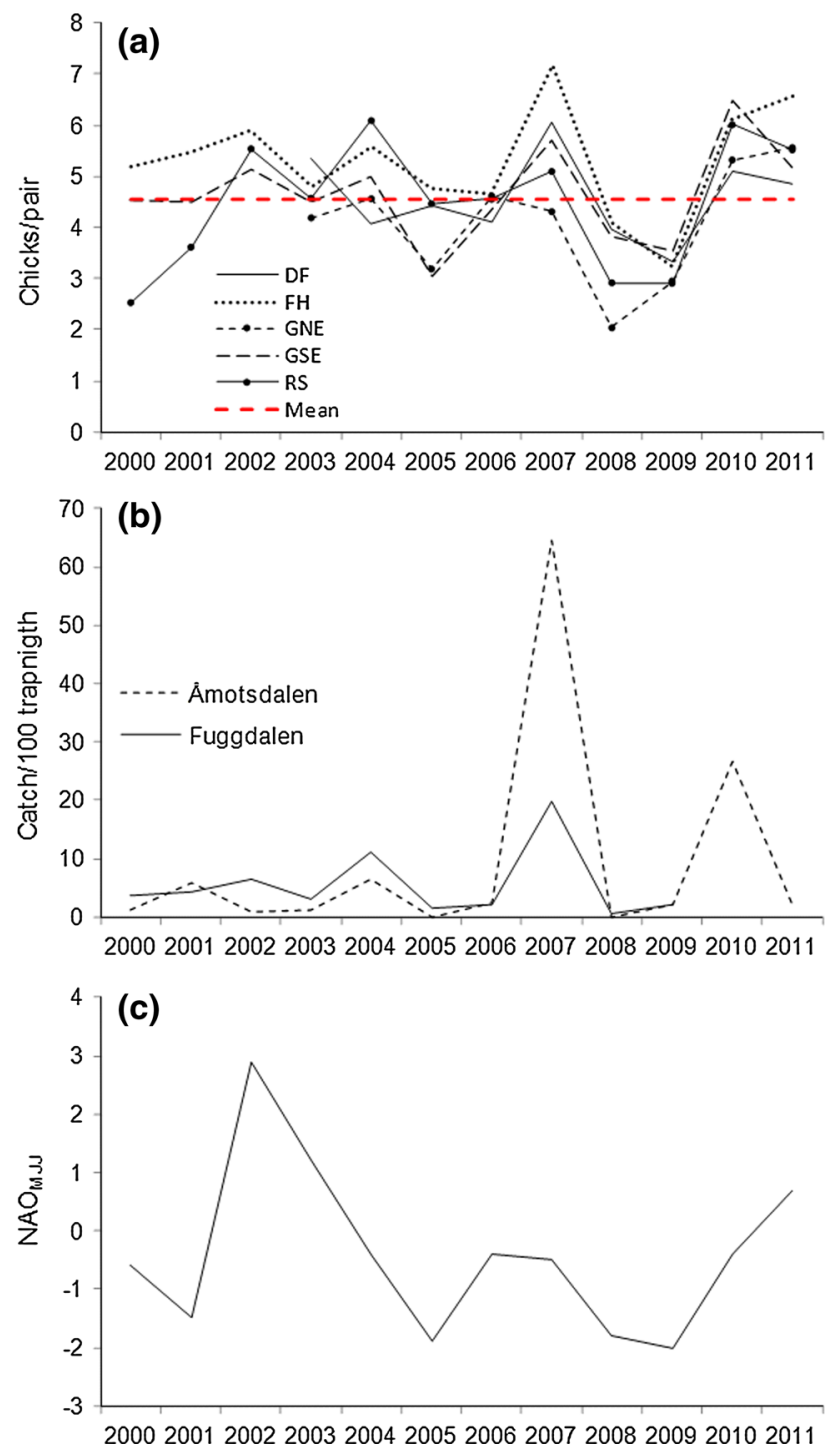

Fig. 2 a Recruitment of juveniles (juveniles/pair) in mountain regions, $\mathbf{b}$ standardized rodent abundance indices and $\mathbf{c}$ the seasonal NAO index for May, June and July between 2000 and 2011. In (a) Dotted horizontal line indicates the overall mean number of juveniles per pair and $R S$ Rondane, $D F$ Dovre and Folldal, $F H$ Forollhogna, GNE Glomma north-east, GSE Glomma south-east. In (b) cross-correlation coefficient between rodent trap sites was 0.89 $(n=10$ years $)$

were also highly synchronous with a correlation coefficient (95\% CI) of $0.89(0.60-0.97)$.

Modelling recruitment as a function of environmental covariates, model selection suggested that models including additive effects of rodent abundance and $\mathrm{NAO}_{\mathrm{MJJ}}$ performed much better than all other candidate models (Table 3). Both variables had a positive effect on recruitment of juveniles (Slope \pm SE; mountain region scale: $\mathrm{NAO}_{\mathrm{MJJ}}=0.53 \pm 0.10$, Rodent $=0.03 \pm 0.01$ and survey area scale: $\quad \mathrm{NAO}_{\mathrm{MJJ}}=0.54 \pm 0.08, \quad$ Rodent $=$ $0.03 \pm 0.01$, Fig. 3). This implies that Willow Ptarmigan
Table 1 Pair-wise cross-correlation coefficients between mountain region recruitment rates (juveniles/pair)

\begin{tabular}{llllllc} 
& $D F$ & $F H$ & GNE & $G S E$ & $R S$ & Number of years \\
\hline$D F$ & & & & & 9 \\
$F H$ & $0.81^{*}$ & & & & 12 \\
$G N E$ & 0.50 & $0.73^{*}$ & & & 9 \\
$G S E$ & $0.64^{* *}$ & $0.79^{*}$ & $0.77^{\star}$ & & 12 \\
$R S$ & 0.53 & $0.67^{*}$ & $0.87^{\star}$ & $0.66^{*}$ & 12 \\
\hline
\end{tabular}

RS Rondane, DF Dovre and Folldal, FH Forollhogna, GNE Glomma northeast, GSE Glomma southeast

$* p$ value $<0.05$

$* * p$ value $<0.1$

Table 2 Mean cross-correlation coefficients for recruitment of juveniles during the period 2000-2011 with confidence intervals (2.5 and $97.5 \%$ percentiles, respectively) based on bootstrap

\begin{tabular}{llll}
\hline & Mean $r$ & $2.5 \%$ & $97.5 \%$ \\
\hline FH & 0.39 & 0.31 & 0.45 \\
DF & 0.52 & 0.42 & 0.62 \\
GNE & 0.61 & 0.51 & 0.71 \\
GSE & 0.63 & 0.55 & 0.71 \\
RS & 0.48 & 0.42 & 0.55 \\
Among all areas & 0.44 & 0.42 & 0.46 \\
Among mountain regions & 0.70 & 0.63 & 0.77 \\
\hline
\end{tabular}

Correlations are between areas within mountain regions (FH, DF, GNS, GSE and RS), among all areas and among mountain regions (for the latter, c.f. Table 1)

RS Rondane, DF Dovre and Folldal, FH Forollhogna, GNE Glomma northeast, GSE Glomma southeast

recruitment was high in years with a high abundance of rodents and positive $\mathrm{NAO}_{\mathrm{MJJ}}$ values. The $\triangle \mathrm{AICc}$ values for the second best supported models were 18.33 and 5.86 at the survey area and mountain region scales, respectively (Table 3). The fixed effects from the most parsimonious models explained 27 and $51 \%$ of the variation in recruitment, while the second ranked models explained 16 and $34 \%$, at the survey area and mountain region scales, respectively. Models with the single effects of either rodent abundance or $\mathrm{NAO}_{\mathrm{MJJ}}$ were not sufficient to explain the observed variation in recruitment of juveniles (Table 3). However, when comparing these two variables, $\mathrm{NAO}_{\mathrm{MJJ}}$ models explained more of the variation in recruitment than rodent abundance models at both scales (Table 3). A sensitivity analysis based on the most preferred model at both scales (Table 3) confirmed the greater influence of $\mathrm{NAO}_{\mathrm{MJJ}}$ than rodent abundance. When holding $\mathrm{NAO}_{\mathrm{MJJ}}$ constant at its mean value and varying the rodent abundance across the observed values, predicted recruitment of juveniles changed from 4.25 to 6.03 juveniles/pair (survey area) and from 4.11 to 6.27 juveniles/pair (mountain region). Similarly, when holding rodent abundance constant and letting 
Table 3 Model selection tables (10 best supported models) based on AICc selection criteria for the survey area scale (a) and mountain region scale (b)

\begin{tabular}{|c|c|c|c|c|c|}
\hline Model & $d f$ & $\mathrm{AICc}$ & $\triangle \mathrm{AICc}$ & logLik & $\begin{array}{l}\text { AICc } \\
\text { weigh }\end{array}$ \\
\hline \multicolumn{6}{|l|}{ (a) } \\
\hline $\mathrm{NAO}_{\mathrm{MJJ}}$, Rodent & 7 & $1,055.80$ & 0.00 & -520.73 & 1.00 \\
\hline $\mathrm{NAO}_{\mathrm{MJJ}}$ & 6 & $1,074.10$ & 18.33 & -530.94 & 0.00 \\
\hline $\begin{array}{l}\text { Rodent, } T_{\text {BROOD }}, \\
\text { RR }_{\text {INC }}\end{array}$ & 8 & $1,077.10$ & 21.28 & -530.32 & 0.00 \\
\hline $\begin{array}{l}\text { Rodent, } T_{\text {BROOD }} \\
\text { RR }_{\text {INC }}, \text { RR }_{\text {PRE-INC }}\end{array}$ & 9 & $1,077.90$ & 22.13 & -529.69 & 0.00 \\
\hline Rodent, $T_{\mathrm{BROOD}}, T_{\mathrm{INC}}$ & 8 & $1,079.50$ & 23.68 & -531.52 & 0.00 \\
\hline Rodent, $\mathrm{RR}_{\mathrm{INC}}$ & 7 & $1,080.30$ & 24.44 & -532.96 & 0.00 \\
\hline Rodent, OPG, $\mathrm{RR}_{\mathrm{INC}}$ & 8 & $1,080.70$ & 24.85 & -532.11 & 0.00 \\
\hline Rodent, $T_{\mathrm{BROOD}}$ & 7 & $1,080.80$ & 25.02 & -533.24 & 0.00 \\
\hline Rodent, OPG, $T_{\mathrm{INC}}$ & 8 & $1,081.20$ & 25.35 & -532.36 & 0.00 \\
\hline Rodent, $T_{\mathrm{INC}}$ & 7 & $1,081.40$ & 25.61 & -533.54 & 0.00 \\
\hline \multicolumn{6}{|l|}{ (b) } \\
\hline $\mathrm{NAO}_{\mathrm{MJJ}}$, Rodent & 6 & 98.40 & 0.00 & -41.87 & 0.91 \\
\hline $\mathrm{NAO}_{\mathrm{MJJ}}$ & 5 & 104.20 & 5.86 & -46.21 & 0.05 \\
\hline Rodent, $\mathrm{RR}_{\mathrm{INC}}$ & 6 & 108.20 & 9.78 & -46.76 & 0.01 \\
\hline Rodent & 5 & 109.90 & 11.52 & -49.04 & 0.00 \\
\hline Rodent, $T_{\text {INC }}$ & 6 & 109.90 & 11.57 & -47.66 & 0.00 \\
\hline $\begin{array}{l}\text { Rodent, } T_{\text {BROOD }}, \\
\text { RR }_{\text {INC }}\end{array}$ & 7 & 110.40 & 12.02 & -46.39 & 0.00 \\
\hline $\begin{array}{l}\text { Rodent, } \mathrm{RR}_{\mathrm{BROOD}} \\
\mathrm{RR}_{\mathrm{INC}}\end{array}$ & 7 & 110.80 & 12.38 & -46.57 & 0.00 \\
\hline $\begin{array}{l}\text { Rodent, } \mathrm{RR}_{\mathrm{INC}}, \\
\text { RR }_{\text {PRE-INC }}\end{array}$ & 7 & 110.80 & 12.42 & -46.59 & 0.00 \\
\hline Rodent, OPG, $\mathrm{RR}_{\mathrm{INC}}$ & 7 & 110.90 & 12.53 & -46.64 & 0.00 \\
\hline $\begin{array}{l}\text { Rodent, } T_{\text {PRE-INC }}, \\
\text { RR }_{\text {INC }}\end{array}$ & 7 & 111.10 & 12.77 & -46.76 & 0.00 \\
\hline
\end{tabular}

$T_{x}$ and $\mathrm{RR}_{x}$ are mean temperature and sum of precipitation (mm.) in period $x$, respectively. $P R E-I N C$ period before incubation, INC incubation period and $B R O O D$ is the period after hatching (for exact dates of the periods, see section "Local weather data" in the methods). OPG is the average day for onset of plant growth within a mountain region (for details, see section "Onset of plant growth" in the methods). $\mathrm{NAO}_{\mathrm{MJJ}}$ is the station-based seasonal NAO index for May, June and July (for details. see section "Large-scale climate variation" in the methods). Rodent is the standardized rodent abundance index (catch/100 trap nights) (for details. see "Rodent abundance data" in the methods)

$\mathrm{NAO}_{\mathrm{MJJ}}$ vary across the observed range of values, recruitment of juveniles was predicted to display a larger change; 3.94-6.59 juveniles/pair (survey area) and 3.79-6.41 juveniles/pair (mountain region).

In general, models including meteorological data or plant growth indices rather than $\mathrm{NAO}_{\mathrm{MJJ}}$ received little support. The best models including such variables consisted of a positive effect of rodents and precipitation during incubation and a negative effect of temperature during the brood period at the survey area scale, and a positive effect of rodents and a positive effect of precipitation during the incubation period at the mountain region scale (Table 3).

The relationship between local climate variables and $\mathrm{NAO}_{\mathrm{MJJ}}$ was generally consistent across the meteorological stations and mountain regions, as the models with an interaction between station or mountain region and $\mathrm{NAO}_{\mathrm{MJJ}}$ generally performed poorer that the additive models (Table 4). For temperature during the incubation period $\left(T_{\text {Inc }}\right)$ and precipitation during the pre-incubation period $\left(\mathrm{RR}_{\mathrm{Pre}-\mathrm{inc}}\right) \Delta \mathrm{AICc}$ was $<2$ (Table 4 ) suggesting that the models were equally supported by the data. Parsimony suggests, however, that the interaction term was not needed to model the relationship, and that effect of $\mathrm{NAO}_{\mathrm{MJJ}}$ on local conditions was similar among the meteorological stations and mountain regions in the study area. Examining parameter estimates from the additive models, confidence intervals for the slope parameter (i.e. the $\mathrm{NAO}_{\mathrm{MJ}}$-effect) did not overlap zero for temperature during the incubation and pre-incubation periods, precipitation during the preincubation period and for the OPG (Table 5). The signs of the coefficients suggested a positive effect of $\mathrm{NAO}_{\mathrm{MJJ}}$ on local temperature during pre-incubation and incubation and on precipitation during pre-incubation, and that high $\mathrm{NAO}_{\mathrm{MJJ}}$ values are related to an early onset of spring.

\section{Discussion}

In this paper we have investigated synchrony in the recruitment of juveniles within and among mountain region populations, and the effect of predation and large-as well as local—scale climate on local and regional recruitment rates in Willow Ptarmigan. First, we found that recruitment of juveniles was synchronous among and within mountain regions in southeastern and central Norway (mean distance between mountain region centrepoints: $96.5 \mathrm{~km}$, c.f. Fig. 1). Second, variation in recruitment of juveniles at both mountain region scale and survey area scale were related to variability in rodent abundance and the NAO during the breeding season $\left(\mathrm{NAO}_{\mathrm{MJJ}}\right)$. Although there were only two rodent trap sites, they were highly synchronous at a distance of $118 \mathrm{~km}$, suggesting that rodent populations elsewhere in the study area also follow a similar pattern.

The relatively strong correlation in recruitment of juveniles among mountain regions, and the strong correlation in abundance indices between rodent trap sites, suggest that spatially separated populations are subject to similar extrinsic environmental forces. The spatial scale of this correlation further suggests that these environmental forces work similarly across large regions. Within mountain regions, correlations in recruitment were more variable 

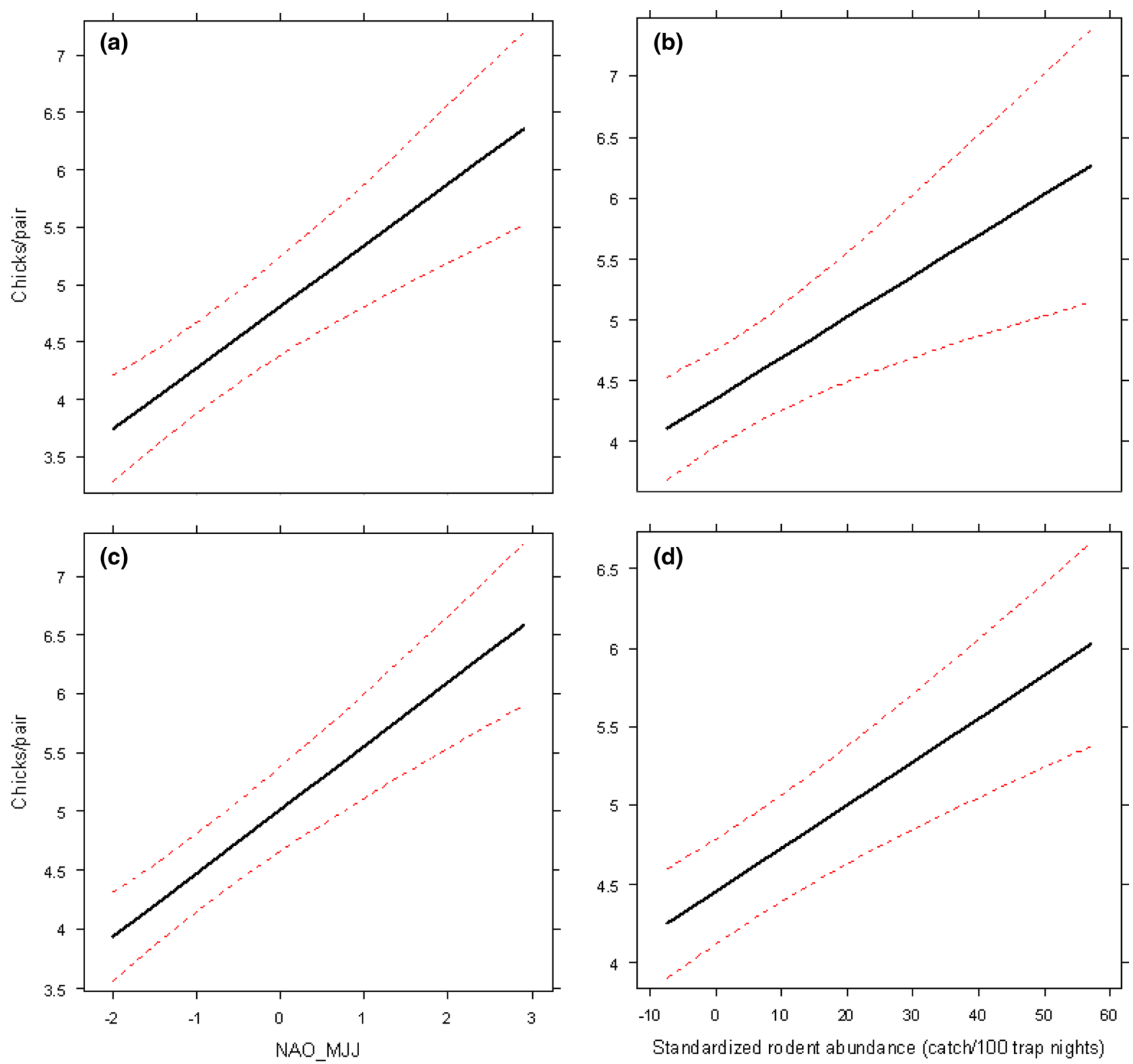

Fig. 3 Number of juveniles/pair plotted against NAO (a, c) and standardized rodent index $(\mathbf{b}, \mathbf{d})$. Top $(\mathbf{a}, \mathbf{b})$ is mountain region scale and below $(\mathbf{c}, \mathbf{d})$ is survey area scale. Slope \pm SE from generalized

mixed effect models; mountain region scale: $\mathrm{NAO}=0.53 \pm 0.10$, Rodent $=0.03 \pm 0.01$ and survey area scale: $\mathrm{NAO}=0.54 \pm 0.08$, Rodent $=0.03 \pm 0.01$

and the average correlation was lower within than between regions. This local variation could arise from variation in local factors such as habitat and predation rates (Tavecchia et al. 2008), but the pattern may also be due to the small size of local populations and low sample sizes making them more vulnerable to demographic stochasticity and sampling variation (Tedesco et al. 2004).

When examining the effects of extrinsic environmental factors on Willow Ptarmigan recruitment, the models gaining the strongest statistical support included both a positive effect of rodent abundance and NAO during May,

June and July. This suggests that a high abundance of rodents in the breeding season and high values of $\mathrm{NAO}_{\mathrm{MJJ}}$ increase recruitment rates in Willow Ptarmigan. The positive effect of rodent abundance on recruitment of juveniles is most likely related to lower predation rates at rodent peaks (Steen et al. 1988b), as predicted by the alternative prey hypothesis (Kjellander and Nordstrom 2003; Hagen 1952). A high abundance of rodents in autumn generally follows high numbers in the preceding spring (Kausrud et al. 2008). High densities of rodents during laying, incubation and early brood rearing periods 
Table 4 Model selection table for models investigating the relationship between $\mathrm{NAO}_{\mathrm{MJJ}}$ and local climate variables (i.e. column Variable)

\begin{tabular}{llrlcll}
\hline $\begin{array}{l}\text { Response } \\
\text { variable }\end{array}$ & Model & $d f$ & AICc & $\Delta$ AICc & $\operatorname{logLik}$ & $\begin{array}{l}\text { AICc } \\
\text { weight }\end{array}$ \\
\hline$T_{\text {Brood }}$ & Additive & 8 & 127.72 & 0.00 & -54.36 & 0.99 \\
& Interaction & 12 & 136.41 & 8.68 & -52.66 & 0.01 \\
$T_{\text {Inc }}$ & Additive & 8 & 160.44 & 0.00 & -70.72 & 0.7 \\
& Interaction & 12 & 162.14 & 1.7 & -65.52 & 0.3 \\
$T_{\text {Pre-inc }}$ & Additive & 8 & 126.53 & 0.00 & -53.77 & 0.98 \\
& Interaction & 12 & 134.46 & 7.93 & -51.68 & 0.02 \\
RR $_{\text {Brood }}$ & Additive & 8 & 474.87 & 0.00 & -227.72 & 0.99 \\
& Interaction & 12 & 485.45 & 10.58 & -226.62 & 0.01 \\
RR $_{\text {Inc }}$ & Additive & 8 & 473.76 & 0.00 & -227.16 & 0.99 \\
& Interaction & 12 & 483.85 & 10.09 & -225.82 & 0.01 \\
RR $_{\text {Pre-inc }}$ & Interaction & 12 & 462.69 & 0.00 & -215.24 & 0.55 \\
& Additive & 8 & 463.11 & 0.43 & -221.84 & 0.45 \\
OPG & Additive & 8 & 314.54 & 0.00 & -147.86 & 0.99 \\
& Interaction & 12 & 323.44 & 8.90 & -146.4 & 0.01 \\
\hline
\end{tabular}

For each local variable, we considered two models, one with interaction between $\mathrm{NAO}_{\mathrm{MJJ}}$ and spatial location (interaction), and one without interaction (additive)

Table 5 Parameter estimates with confidence intervals (2.5 and $97.5 \%$ percentiles, respectively) based on bootstrap for the effect of $\mathrm{NAO}_{\mathrm{MJJ}}$ on local conditions, from the additive models in Table 4

\begin{tabular}{lccc}
\hline Variable & Estimate & $2.50 \%$ & $97.50 \%$ \\
\hline$T_{\text {Brood }}$ & -0.41 & -0.02 & 0.23 \\
$T_{\text {Inc }}$ & $0.94^{*}$ & 0.34 & 1.62 \\
$T_{\text {Pre-inc }}$ & $0.4^{*}$ & 0.002 & 0.81 \\
$\mathrm{RR}_{\text {Brood }}$ & 4.8 & -5.82 & 14.69 \\
$\mathrm{RR}_{\text {Inc }}$ & 0.51 & -7.05 & 7.99 \\
$\mathrm{RR}_{\text {Pre-inc }}$ & $6.3^{*}$ & 1.25 & 11.54 \\
OPG & $-1.58^{*}$ & -3.1 & -0.17 \\
\hline
\end{tabular}

* Confidence limits not overlapping zero

may thus indirectly reduce predation on ptarmigan eggs and chicks if generalist predators prefer easily caught rodent prey. Interestingly, our models explained a similar amount of variation in recruitment as the models of Steen et al. (1988b). However, contrary to Steen et al. (1988b), more of the variation in our models was explained by weather conditions $\left(\mathrm{NAO}_{\mathrm{MJJ}}\right)$ than rodent abundance.

None of the models that included local meteorological variables received as much support as those including the $\mathrm{NAO}_{\mathrm{MJJ}}$ index. One possible reason for this is that local meteorological data can contain noise which may reduce the predictability of such data. Further, local data such as temperature and precipitation can be interpreted in many ways and it might be difficult to identify important variables (Hallett et al. 2004). The NAO index, however, might be more useful as it integrates the effects of several local weather variables simultaneously. Our finding that recruitment of juveniles is more related to large-scale climate than local climate is in agreement with other studies (Hallett et al. 2004; Stenseth et al. 2003).

The effect of $\mathrm{NAO}_{\mathrm{MJJ}}$ provides limited information about the underlying mechanisms unless it can be related to some local climatic condition. It is already known that positive values of winter NAO are related to warm and moist conditions in Western Europe (Hurrell 1995). We found that $\mathrm{NAO}_{\mathrm{MJJ}}$ had a similar effect on local conditions in our study area. In general, there was a significant positive relationship between $\mathrm{NAO}_{\mathrm{MJJ}}$ and temperatures during the incubation and pre-incubation periods and between $\mathrm{NAO}_{\mathrm{MJJ}}$ and precipitation in the pre-incubation period. High temperatures together with precipitation during this period (May to late June) will probably accelerate snow melt in mountain areas, and might thus be one of the reasons for the positive effect of $\mathrm{NAO}_{\mathrm{MJJ}}$ on recruitment of juveniles (Slagsvold 1975; Steen et al. 1988a, b). This is further supported by the fact that OPG was negatively related to $\mathrm{NAO}_{\mathrm{MJJ}}$, i.e. that positive $\mathrm{NAO}_{\mathrm{MJ}}$ values accelerate plant growth. Potential mechanisms behind the climate effect detected here might thus be a positive effect of early plant growth on maternal nutrition (Moss and Watson 1984), food availability for chicks (Erikstad and Spidso 1982; Erikstad 1985a; Erikstad and Andersen 1983) and the timing of laying (Erikstad et al. 1985), which are all known to affect recruitment of juveniles positively.

In North American Willow Ptarmigan, the probability of renesting was higher in a year with normal weather than during a year with harsh weather (Martin and Wiebe 2004), and renesting can potentially increase yearly recruitment (Martin et al. 1989; Parker 1985). Sandercock and Pedersen (1994) found that females that renested had larger eggs in their first clutch than females that did not, suggesting that renesting probability could be related to female nutrition. Similarly, in Capercaillie, renesting increased recruitment (Storaas et al. 2000) and the renesting probability was highest for heavy females. Favourable conditions in spring may thus buffer some of the effect of egg predation through increased renesting frequency.

It is interesting to observe that recruitment of juveniles in all mountain regions was above average in 2011 when rodent populations in Åmotsdalen collapsed (c.f. Figs. 2, 3). Since rodent populations were highly synchronized across the study area, it is likely that a collapse also occurred in Fuggdalen and other areas within the study region that year. This may be a result of a mismatch between rodent abundance in spring and autumn because of a collapse in the rodent population during summer (c.f. Kausrud et al. 2008; Wegge and Storaas 1990). Alternatively, the strong positive 
$\mathrm{NAO}_{\mathrm{MJ}}$ that year may have reduced the otherwise negative effect of predation that would be expected (e.g. through increased renesting frequency). In connection to this and in contrast to Steen et al. (1988b), it is also interesting to see that at both spatial scales, the relative effects of large-scale climate were stronger than the effect of local rodent abundance (predation). There might be several reasons for this: First, this might be related to the scale at which the rodent and $\mathrm{NAO}_{\mathrm{MJJ}}$ are collected. As for the local climate data, the rodent data were measured at a finer scale than the NAO index, and might then be more vulnerable to demographic stochasticity and sampling variation (Tedesco et al. 2004). Strong correlation between rodent trap sites, however, suggests that this is not the case for this data. Second, the rodent abundance might be a good index for predation rates, but not a perfect one. Rodent dynamics are complex with regard to the timing of a collapse, and the Willow Ptarmigan is subject to predation from other non-rodent-eating specialist predators, as well as rodent-eating generalist predators (Munkebye et al. 2003), and this might induce unexplained variability. Third, climatic forcing on population dynamics of ptarmigans might potentially have become more pronounced in recent years, due to the collapse in small rodent population cycles (Kausrud et al. 2008; Steen et al. 1988b; Ims et al. 2008). It is likely that other species, such as ptarmigan, were entrained in the rodent cycle by shared predators when regular population fluctuations existed (Hagen 1952; Kjellander and Nordstrom 2003). This link may have weakened since the late 1980s and mid 1990s as small rodent fluctuations became more irregular (Kausrud et al. 2008; Ims et al. 2008) and the effects of environmental perturbations and climatic variation became more pronounced in the dynamics of ptarmigan.

In this study we demonstrate that recruitment of juvenile Willow Ptarmigan is synchronized across south-central Norway. The seasonal NAO during May, June and July and rodent abundance positively affect recruitment of juveniles, and are, therefore, possible drivers of the observed spatial synchrony. We suggest that global climate change may indirectly affect Willow Ptarmigan recruitment through its effects on the rodent cycle (Ims et al. 2008; Kausrud et al. 2008), but also directly by affecting plant growth and snow conditions during spring.

Acknowledgments This work was carried as a part of the Grouse Management Project 2006-2011 funded by Norwegian Research Council and Norwegian Directorate for Nature Management. Additional funding was received from Hedmark University College and Norwegian Institute for Nature Research (NINA). We are grateful to all the dog handlers who have collected the field data for this project, to Stein-Rune Karlsen for providing data on plant growth and to $\varnothing$ ystein Wiig and Erik Framstad for providing data on rodent abundance form Fuggdalen and Åmotsdalen, respectively. We also wish to thank Jos M. Milner for valuable comments and help with the English and to Dan Chamberlain for a constructive review that greatly improved the manuscript. Collection of data in this study complies with the Norwegian laws.

Open Access This article is distributed under the terms of the Creative Commons Attribution License which permits any use, distribution, and reproduction in any medium, provided the original author(s) and the source are credited.

\section{References}

Barnagaud JY, Crochet PA, Magnani Y, Laurent AB, Menoni E, Novoa C, Gimenez O (2011) Short-term response to the North Atlantic Oscillation but no long-term effects of climate change on the reproductive success of an alpine bird. J Ornithol 152(3):631-641. doi:10.1007/s10336-010-0623-8

Barton K (2013) MuMIn: Multi-model inference. R package version1.9.5. http://CRAN.R-project.org/package=MuMIn

Bates D, Maechler M, Bolker B (2011) lme4: Linear mixed-effects models using S4 classes. R package version 0.999375-41. http:// CRAN.R-project.org/package $=1 \mathrm{me} 4$

Beyer HL (2012) Geospatial modelling environment (version 0.6.0.0). (software). URL: http://www.spatialecology.com/gme

Buckland ST, Anderson DR, Burnham KP, Laake JL, Borchers DL, Thomas L (2001) Introduction to distance sampling: estimating abundance of biological populations. Oxford Univerity Press Inc, New York

Burnham KP, Anderson DR (2002) Model selection and multimodel inference: a practical information-theoretic approach. Springer, New York

Cornulier T, Yoccoz NG, Bretagnolle V, Brommer JE, Butet A, Ecke F, Elston DA, Framstad E, Henttonen H, Hornfeldt B, Huitu O, Imholt C, Ims RA, Jacob J, Jedrzejewska B, Millon A, Petty SJ, Pietiainen H, Tkadlec E, Zub K, Lambin X (2013) Europe-wide dampening of population cycles in keystone herbivores. Science 340(6128):63-66. doi:10.1126/science.1228992

Crawley MJ (2007) The R book. Wiley \& sons, Chichester

Erikstad KE (1985a) Growth and survival of willow grouse chicks in relation to home range size, brood movements and habitat selection. Ornis Scandinavica 16(3):181-190

Erikstad KE (1985b) Territorial breakdown and brood movements in willow grouse Lagopus 1. lagopus. Ornis Scandinavica 16(2):95-98. doi:10.2307/3676473

Erikstad KE, Andersen R (1983) The effect of weather on survival, growth-rate and feeding time in different sized willow grouse broods. Ornis Scandinavica 14(4):249-252. doi:10.2307/3676311

Erikstad KE, Spidso TK (1982) The influence of weather on foodintake, insect prey selection and feeding-behavior in willow grouse chicks in northern norway. Ornis Scandinavica 13(3): 176-182. doi:10.2307/3676295

Erikstad KE, Pedersen HC, Steen JB (1985) Clutch size and egg size variation in willow grouse Lagopus 1. lagopus. Ornis Scandinavica 16(2):88-94. doi:10.2307/3676472

Forchhammer MC, Post E (2000) Climatic signatures in ecology. Trends Ecol Evol 15(7):286. doi:10.1016/s0169-5347(00)01869-3

Framstad E (2012) The terrestrial ecosystems monitoring programme in 2011: ground vegetation, epiphytes, small mammals and birds. Summary of results vol 840. NINA, Trondheim

Grenfell BT, Wilson K, Finkenstadt BF, Coulson TN, Murray S, Albon SD, Pemberton JM, Clutton-Brock TH, Crawley MJ (1998) Noise and determinism in synchronized sheep dynamics. Nature 394(6694):674-677 
Hagen Y (1952) Rovfuglene og viltpleien. Gyldendal norsk forlag, Oslo (In Norwegian)

Hallett TB, Coulson T, Pilkington JG, Clutton-Brock TH, Pemberton JM, Grenfell BT (2004) Why large-scale climate indices seem to predict ecological processes better than local weather. Nature 430(6995):71-75. doi:10.1038/nature02708

Hannon SJ, Martin K (2006) Ecology of juvenile grouse during the transition to adulthood. J Zool 269(4):422-433. doi:10.1111/j. 1469-7998.2006.00159.x

Hornell-Willebrand M, Marcstrom V, Brittas R, Willebrand T (2006) Temporal and spatial correlation in chick production of willow grouse Lagopus lagopus in Sweden and Norway. Wildl Biol 12(4):347-355

Hurrell JW (1995) Decadal trends in the north-atlantic oscillationregional temperatures and precipitation. Science 269(5224): 676-679. doi:10.1126/science.269.5224.676

Hurrell J, National Center for Atmospheric Research Staff (eds.) (2013) The climate data guide: Hurrell North Atlantic Oscillation (NAO) Index (station-based). Retrieved from https:// climatedataguide.ucar.edu/guidance/hurrell-north-atlantic-oscilla tion-nao-index-station-based. Accessed 27 Jun 2013

Ims RA, Andreassen HP (2000) Spatial synchronization of vole population dynamics by predatory birds. Nature 408(6809): 194-196

Ims RA, Henden JA, Killengreen ST (2008) Collapsing population cycles. Trends Ecol Evol 23(2):79-86. doi:10.1016/j.tree.2007. 10.010

Johnsgard PA (1983) The grouse of the world. Croom Helm Ltd., Kent

Karlsen SR, Ramfjord H, Hogda KA, Johansen B, Danks FS, Brobakk TE (2009) A satellite-based map of onset of birch (Betula) flowering in Norway. Aerobiologia 25(1):15-25. doi:10.1007/ s10453-008-9105-3

Karlsen SR, Høgda KA, Johansen B, Holten JI, Wehn S (2012) Etablering av overvåkning av vekstsesongen langs et kystinnland transekt i Midt Norge: ett delprosjekt innen GLORIA Norge, vol 4/2012. Norut Troms $\varnothing$, Troms $\varnothing$

Kausrud KL, Mysterud A, Steen H, Vik JO, Ostbye E, Cazelles B, Framstad E, Eikeset AM, Mysterud I, Solhoy T, Stenseth NC (2008) Linking climate change to lemming cycles. Nature 456(7218):93-98. doi:10.1038/nature07442

Kjellander P, Nordstrom J (2003) Cyclic voles, prey switching in red fox, and roe deer dynamics - a test of the alternative prey hypothesis. Oikos 101(2):338-344. doi:10.1034/j.1600-0706. 2003.11986.x

Kvasnes MAJ, Storaas T, Pedersen HC, Bjork S, Nilsen EB (2010) Spatial dynamics of Norwegian tetraonid populations. Ecol Res 25(2):367-374. doi:10.1007/s11284-009-0665-7

Kvasnes MAJ, Pedersen HC, Solvang H, Storaas T, Nilsen EB (2013) Spatial distribution and settlement strategies in willow ptarmigan. Manuscript submitted for publication

Lande R, Engen S, Sæther BE (2003) Stochastic population dynamics in ecology and conservation, 1st edn., Oxford series in ecology and evolutionOxford University Press, Oxford

Martin K, Wiebe KL (2004) Coping mechanisms of alpine and arctic breeding birds: extreme weather and limitations to reproductive resilience. Integr Comp Biol 44(2):177-185. doi:10.1093/icb/44. 2.177

Martin K, Hannon SJ, Rockwell RF (1989) Clutch size variation and patterns of attrition in fecundity of willow ptarmigan. Ecology 70(6):1788-1799. doi:10.2307/1938112

Moran PAP (1953) The statistical analysis of the canadian lynx cycle. II. Synchronization and meteorology. Aust J Zool 1:291-298 (Chp 294, Chp 295, Chp 210)

Morris WF, Pfister CA, Tuljapurkar S, Haridas CV, Boggs CL, Boyce MS, Bruna EM, Church DR, Coulson T, Doak DF, Forsyth S, Gaillard
J-M, Horvitz CC, Kalisz S, Kendall BE, Knight TM, Lee CT, Menges ES (2008) Longevity can buffer plant and animal populations against changing climatic variability. Ecology 89:19-25

Moss R, Watson A (1984) Maternal nutrition, egg quality and breeding success of scottish ptarmigan lagopus-mutus. Ibis 126(2):212-220. doi:10.1111/j.1474-919X.1984.tb08000.x

Munkebye E, Pedersen HC, Steen JB, Brøseth H (2003) Predation of eggs and incubating females in willow ptarmigan Lagopus 1. lagopus. Fauna Norvegica 23:1-8

Myrberget S (1988) Demography of an island population of willow ptarmigan in northern Norway. In: Bergerud AT, Gratson MW (eds) Adaptive strategies and population Ecology of northern grouse. University of Minnesota press, Minneapolis, pp 379-419

Nakagawa S, Schielzeth H (2013) A general and simple method for obtaining R2 from generalized linear mixed-effects models. Methods Ecol Evol 4(2):133-142. doi:10.1111/j.2041-210x. 2012.00261.x

Newton I (1998) Population limitation in birds. Academic Press, Boston

Novoa C, Besnard A, Brenot JF, Ellison LN (2008) Effect of weather on the reproductive rate of Rock Ptarmigan Lagopus muta in the eastern Pyrenees. Ibis 150(2):270-278. doi:10.1111/j.1474919X.2007.00771.x

Odland A (2011) Estimation of the growing season length in alpine areas: effects of snow and temperatures. In: Schmidt JG (ed) Alpine environment: geology, ecology and conservation. Nova Science Publishers, New York, pp S85-S134

Parker H (1985) Compensatory reproduction through renesting in willow ptarmigan. J Wildl Manag 49(3):599-604. doi:10.2307/ 3801679

Pedersen HC, Steen JB (1979) Behavioural thermoregulation in willow ptarmigan chicks Lagopus lagopus. Ornis Scandinavica 10(1):17-21. doi:10.2307/3676339

Pedersen HC, Steen H, Kastdalen L, Svendsen W, Brøseth H (1999) Betydningen av jakt på lirypebestander: framdriftsrapport 1996-1998. In: NINA oppdragsmelding pp 43s. Norsk institutt for naturforskning, Trondheim (in Norwegian with English summary)

Pedersen HC, Steen H, Kastdalen L, Broseth H, Ims RA, Svendsen W, Yoccoz NG (2004) Weak compensation of harvest despite strong density-dependent growth in willow ptarmigan. Proc R Soc Lond Ser B Biol Sci 271(1537):381-385

R-Core-Team (2012) R: A language and environment for statistical computing. R Foundation for Statistical Computing, Vienna, Austria. ISBN 3-900051-07-0, http://www.R-project.org/

Reed TE, Grotan V, Jenouvrier S, Saether BE, Visser ME (2013) Population growth in a wild bird is buffered against phenological mismatch. Science 340(6131):488-491. doi:10.1126/science. 1232870

Saether BE, Sutherland WJ, Engen S (2004) Climate influences on avian population dynamics. In: Moller AP, Fielder W, Berthold P (eds) Birds and Climate Change, vol 35. Academic Press Ltd, London, pp 185-209. doi:10.1016/s0065-2504(04)35009-9

Sandercock BK, Pedersen HC (1994) The effect of renesting ability and nesting attempt on egg-size variation in willow ptarmigan. Can J Zool-Revue Canadienne De Zoologie 72(12):2252-2255. doi:10.1139/Z94-301

Sandercock BK, Martin K, Hannon SJ (2005) Demographic consequences of age-structure in extreme environments: population models for arctic and alpine ptarmigan. Oecologia 146:13-24

Sandercock BK, Nilsen EB, Brøseth H, Pedersen HC (2011) Is hunting mortality additive or compensatory to natural mortality? Effects of experimental harvest on the survival and cause specific mortality of willow ptarmigan. J Anim Ecol 80:244-258

Selas V, Sonerud GA, Framstad E, Kalas JA, Kobro S, Pedersen HB, Spidso TK, Wiig O (2011) Climate change in Norway: warm 
summers limit grouse reproduction. Popul Ecol 53(2):361-371. doi:10.1007/s10144-010-0255-0

Slagsvold T (1975) Production of young by the Willow Grouse Lagogus lagopus (L.) in Norway in relation to temperature. Nor J Zool 23:269-275

Smith A, Willebrand T (1999) Mortality causes and survival rates of hunted and unhunted willow grouse. J Wildl Manag 63(2):722-730

Steen JB, Haugvold OA (2009) Cause of death in willow ptarmigan Lagopus 1. lagopus chicks and the effect of intensive, local predator control on chick production. Wildl Biol 15(1):53-59. doi:10.2981/07-073

Steen JB, Andersen O, Saebo A, Pedersen HC, Erikstad KE (1988a) Viability of newly hatched chicks of willow ptarmigan Lagopus 1. lagopus. Ornis Scandinavica 19(2):93-96

Steen JB, Steen H, Stenseth NC, Myrberget S, Marcstrom V (1988b) Microtine density and weather as predictors of chick production in willow ptarmigan, Lagopus. 1. Lagopus. Oikos 51(3):367-373

Stenseth NC, Mysterud A, Ottersen G, Hurrell JW, Chan KS, Lima M (2002) Ecological effects of climate fluctuations. Science 297(5585):1292-1296. doi:10.1126/science.1071281

Stenseth NC, Ottersen G, Hurrell JW, Mysterud A, Lima M, Chan KS, Yoccoz NG, Adlandsvik B (2003) Studying climate effects on ecology through the use of climate indices: the North Atlantic Oscillation, El Nino Southern Oscillation and beyond. Proc R
Soc Lond Ser B-Biol Sci 270(1529):2087-2096. doi:10.1098/ rspb.2003.2415

Storaas T, Wegge P, Kastdalen L (2000) Weight-related renesting in capercaillie Tetrao urogallus. Wildl Biol 6(4):299-303

Tavecchia G, Minguez E, Leon D, Louzao M, Oroi D (2008) Living close, doing differently: small-scale asynchrony in demography of two species of seabirds. Ecology 89(1):77-85

Tedesco PA, Hugueny B, Paugy D, Fermon Y (2004) Spatial synchrony in population dynamics of West African fishes: a demonstration of an intraspecific and interspecific Moran effect. J Anim Ecol 73(4):693-705. doi:10.1111/j.0021-8790.2004. 00843.x

Wegge P, Kastdalen L (2007) Pattern and causes of natural mortality of capercaille, Tetrao urogallus, chicks in a fragmented boreal forest. Ann Zool Fenn 44(2):141-151

Wegge P, Storaas T (1990) Nest loss in capercaillie and black grouse in relation to the small rodent cycle in Southeast Norway. Oecologia 82:527-530

Westerskov K (1956) Age determination and dating nesting events in the willow ptarmigan. J Wildl Manag 20:274-279

Wielgolaski FE, Nordli O, Karlsen SR, O'Neill B (2011) Plant phenological variation related to temperature in Norway during the period 1928-1977. Int J Biometeorol 55(6):819-830. doi:10. 1007/s00484-011-0467-9 